\title{
"Never argue with the Gallup Poll": Thomas Dewey, Civil Rights and the Election of 1948
}

\author{
SIMON TOPPING
}

Thomas Dewey, the progressive Republican governor of New York from I 942 to I 954 famously "snatched defeat from the jaws of victory" in the presidential election of I 948 . It was an election that everyone, with the possible exception of Harry S. Truman, had expected Dewey to win. Truman, like much of the historiography, credited his victory to the farm vote, and this was undoubtedly an important factor, but it is clear that without the votes of African Americans Truman could not have won. ${ }^{1}$ This piece will examine why Dewey lost, surveying his record on civil rights as governor (arguably the best in the nation) and his abject failure to convert, indeed, to even attempt to convert, this record into African American votes in 1948. This failure is made more curious by the fact that he was constantly being warned by African American Republicans and his closest confidante about the pivotal nature of the African American vote. Yet Dewey, a notoriously lethargic campaigner, would ignore their admonishments.

By 1944 the African American vote in key northern states could decide a close presidential election; in 1948 it did. ${ }^{2}$ That Truman had many achievements in civil rights is not in doubt, nevertheless, he was a reluctant convert to the cause and the Grand Old Party (GOP) missed an excellent opportunity to exploit Democratic divisions on the issue. In addition, it

Simon Topping is a lecturer in American History at the University of Wales, Bangor.

${ }^{1}$ Scholars of the Republican party certainly believe that the farm vote was crucial. See, for example, Jules Abels, Out of the Jaws of Victory (New York: Holt, Rinehart and Winston, 1959), I7 I and 290, Kenneth W. Thompson (ed.), Lessons for Defeated Presidential Candidates (New York and London: University Press of America, Lanham, I994), 107-08, Herbert Brownell and John Burke, Advising Ike: The Memoirs of Herbert Brownell (University Press of Kansas, 1983), 80, Malcolm Moos, The Republicans: A History of their Party (New York: Random House, 1956), 444.

2 For a detailed discussion of the African American vote in the election of I 944 see Simon Topping, "The Republican and Civil Rights, 1928-1948," unpublished PhD thesis, University of Hull, 2002, 31 5-38. 
is apparent that the blame for this rests largely with Thomas Dewey who, armed with the knowledge that the African American vote could be decisive, as well as having a good record on civil rights, refused to do anything to win it.

Quite simply, if Dewey had won Ohio, California and Illinois he would have become President. A shift of only 3,500 votes would have given Ohio to Dewey; with a shift of 16,500 votes, he would have won Illinois; in fact, Truman's I 30,000 majority in African American areas of Chicago was four times his Illinois majority. A shift of 9,000 votes would have given him California. In all, a shift of only 29,000 votes out of I0,66 I,000 cast in three pivotal states would have given Dewey overall victory. With a little more care on Dewey's part, African Americans could have provided these votes.

Dewey's slight stature and ample self-belief provided an endless source of amusement for journalists and other commentators during his presidential campaigns of 1944 and I $948 .^{3}$ This did not, however, mask the impression that he lacked any real political principles and that he diligently followed public opinion and then acted accordingly. His faith in polls was well-known. In I940 he had declared: "never argue with the Gallup Poll. It has never been wrong and I very much doubt that it ever will be."4 Many African Americans shared the concerns about Dewey's character, yet he had an unparalleled record on civil rights, passing more racially progressive legislation than any other governor by I948. Why then did a candidate with an unsurpassed record on civil rights fail to win more than a fraction of the African American vote?

The Party of Lincoln had lost touch with African American voters since the election of Franklin Roosevelt in 1932, but Dewey initially seemed to offer the GOP a way to reconnect with this previously most loyal of constituencies. In early 1942 he began trying to garner support among African Americans for his gubernatorial bid by endorsing the Pittsburgh Courier's "Double V" campaign. ${ }^{5}$ Citing the "sacred memory" of Lincoln, he told the

${ }^{3}$ He was variously described as the "bridegroom on a wedding cake," being able to "strut sitting down," suffering from "intellectual halitosis" and also as "a self-made man who worshipped his creator." Quotations from Moos, The Republicans, 42 5, and Sterling Morton to Alfred Landon, 3 January 1947, cited in David Reinhard, The Republican Right Since 1945 (University Press of Kentucky, I983), 40.

${ }^{4}$ Dewey to Alfred M. Landon, 6 June 1944, cited in Barry K. Beyer, Thomas E. Dewey, 1937-1947: A Study in Political Leadership (New York and London: Garland Publishing, Inc., 1979), 73. Also cited in Richard Polenberg, War and Society: The United States, I941-1945 (Westport, CT: Greenwood Press, I972), 2 io.

5 The Courier urged African Americans to fight for victory over tyranny abroad and discrimination at home. 
Courier that America's enemies at home were "intolerance, injustice and the tyranny of ignorance." 6

The Republican Party's platform in the New York gubernatorial election advocated equal opportunity regardless of race and condemned discrimination as a "mockery of democracy." "During the campaign Dewey made several speeches denouncing discrimination in industry and promised to enforce the state's existing civil rights' law. ${ }^{8}$ He demanded that New Yorkers rid themselves of "the millstone of discrimination, prejudice and intolerance," declaring it "absurd to talk about eradicating evils in other countries when we have not wiped out those evils at home."

In an interview with the Amsterdam Star-News, Dewey again vowed to fight discrimination, promising to make existing anti-discrimination laws effective. ${ }^{10}$ Dewey told the Star that African Americans should not suspend their demands for civil rights because of the war. Dewey's response to someone in his administration discriminating against African Americans was simple: "I would fire him on the spot."11 As governor, Dewey declared that he "would tolerate no caste system. I believe that no job is too big or too good for a qualified Negro to fill."

Dewey also made two speeches to African American audiences late in the campaign. In the first at Union Baptist Church, he told his audience that America's diversity gave it strength, and he recognised that African Americans did not want "special consideration just because of [their] color," merely the "end of under-privilege ... discrimination and prejudice" and the rights they were entitled to as American citizens. ${ }^{13}$

Dewey's second speech was in Harlem. He touched upon similar themes but this time he also assailed the current Democratic administration in New York, for example, for paying African Americans and whites different

6 "Statement made by Thomas Dewey for the Pittsburgh Courier," I 2 February I 942. Thomas E. Dewey Papers (henceforth TED), Series I 2, Box 2, File 42.

7 Republican manifesto for the 1942 New York gubernatorial election, 29 August 1942, cited in the Papers of the National Association for the Advancement of Colored People (henceforth NAACP Papers), part I 8, series B, reel i I, frame 296.

8 Ibid., Thomas Dewey, campaign speeches dated is October, I 942 and 26 October, I942, I8, B, II, 29I-2.

${ }^{9}$ Ibid.

10 Ibid., Thomas Dewey, interview with Carl Lawrence, Amsterdam Star-News, 29 August I 942, I 8, B, I I, 0296-0297. This was not the most rigorous of interrogations.

11 "Interview with Mr Dewey for Amsterdam Star-News," 26 October i 942, TED, S9, B I o, I I.

12 Ibid.

13 "Address by Thomas E. Dewey at Union Baptist Church, New York City, October i 9, I 942 ” TED, S9, Bio, F2. 
pay for same jobs; Dewey vowed to rectify this. ${ }^{\mathbf{1 4}}$ He concluded: "we cannot ask people to put their trust in a democracy that does not exist for them." 15 These were forthright words, particularly from a leading Republican, but they also appear to represent Dewey's last major campaign utterances to or about African Americans in his political career. ${ }^{\mathbf{1 6}}$

\section{“ONE OF THE GREAT SOCIAL ADVANCES OF OUR TIME”: NEW YORK'S SADC}

After his election as governor of New York in I942, the Empire State's first Republican chief executive in twenty years, Dewey made a number of notable African American appointments, but his overall record in his first term never quite matched his campaign rhetoric. ${ }^{17}$ The brightest aspect of Dewey's first administration was the universally praised appointment, in September I943, of Francis Rivers as Justice of the City Court in New York, the first African American to hold such a high judicial post in the state. ${ }^{18}$ Dewey, however, soon alienated African American opinion by thwarting attempts to pass a law outlawing employment discrimination in New York. ${ }^{19}$ He argued that the proposed law was ill-conceived and unworkable; his critics countered that he lacked the courage and principles to support it. ${ }^{20}$

14 Ibid., "Address by Thomas E. Dewey, Republican candidate for governor, at a rally in public school I 36, Edgecomb Avenue and I 35 th Street, Monday evening, Oct. 26, I 942 ." This speech is also available in the NAACP Papers, I8, B, I I, 05 I6-0519.

15 Ibid.

${ }^{16}$ Certainly, there is nothing in Dewey's Papers, the NAACP Papers or the New York Times between 1942 and 1948 to challenge this assertion.

17 The NAACP analysed Dewey's early speeches as governor and found: "no specific promises on Dewey's part" on African American appointments. Memorandum from Julia Baxter to Walter White, 4 May i 943, NAACP Papers, I 8, B, i I, 0293.

${ }^{18}$ For comment on Rivers's appointment see New York Times (henceforth NYT), i 8 September i943, pi6. Amsterdam Star-News, 25 September i 943. TED, S7, B62, F43. Tobias to Dewey, 4 November 1943; TED, $\mathrm{S}_{4}, \mathrm{~B}_{1} 85, \mathrm{~F}_{1} 8$. Among Dewey's other significant appointees were Bertha Diggs as Secretary of Labor, and three African American Assistant Attorney Generals. "Appointments of Colored People in State Employ made by Governor Dewey," undated. TED, $\mathrm{S}_{7}, \mathrm{~B}_{3}, \mathrm{~F}_{\mathrm{I}}$.

19 For a full account of the initial failed attempt to pass an SADC, and civil rights during Dewey's early years as governor, see Topping, "The Republican Party," 287-31 5 .

${ }^{20}$ For comment on the original fair employment law see NAACP press release, "Wrong choice made on FEPC, Dewey is told," 23 March I944, NAACP Papers, I 8, B, I I, 0528. NYT, i 8 March 1944, I and io. African American Republican Robert R. Church told Dewey that the passage of the SADC by a Republican "would have a far reaching effect on Colored citizens throughout this country." Telegram from Church to Dewey, Is March 1944, NAACP Papers, I 8, B, I I, 0329. NAACP press release, "Wrong choice made on FEPC, Dewey is told," 23 March I 944, 0338 . Also quoted in "Reveal Line of attack against 
The failure of this law represented a major blow to Dewey's progressive credentials, but he did eventually support fair employment legislation. Passed in early 1945, New York's State Anti-Discrimination Commission (SADC) was both unprecedented and enormously controversial as it outlawed discrimination in employment on the basis of race or religion. Initially, Dewey seemed reluctant to wholeheartedly endorse the bill; but he soon overcame his reticence, describing it as "one of the great social advances of our time." 21 The idea of the state government acting as an enforcer of minority rights was a radical departure, while the prospect of a Republican governor forcing it through, was more radical still.

Dewey's achievement in shepherding the bill through the state legislature is all the more remarkable as many other Republicans remained uneasy about it and, according to the New York. Times, wanted "it beaten or at least [to] extract most of its teeth." 22 Dewey apparently told a delegation demanding the passage of the bill, including Francis Rivers and the NAACP's Thurgood Marshall, that he wanted it passed without amendments. ${ }^{23}$

Dewey signed the SADC or Ives-Quinn bill into law on I 2 March I945, but he was not as enthusiastic about the law as he appeared publicly. He reportedly exclaimed to Irving Ives, the Republican state senator who had fought vigorously to have the bill passed: "for God's sake, Irv, you really care about this thing. Why?" Ives apparently replied, "for God's sake."24 Dewey's ambivalence did not prevent him from taking credit for the law; but in doing so, he tended to stress the "undramatic" approach that it took. Democratic state chairman Paul Fitzpatrick attacked Dewey for claiming credit for the law, arguing that "public opinion was far ahead of him and he caught up with it only as a matter of political expediency.",25

Regardless of Dewey's motivation, the law was effective and did eliminate some of the discrimination faced by African Americans and other minorities. It rid New York of Jim Crow trains and saw four times as many African American women employed in sales and clerical work. It also set precedents for other civil rights legislation during Dewey's tenure. On 5 April 1948 he

the FEPC," Plaindealer, 3 I March i 944, 4. See also, "Negro Congress claim Dewey supported Jim Crow Bilbo," Plaindealer, 7 April 1944, 4, "Tobias reveals facts behind Dewey's letdown of Negroes," Plaindealer, I 2 May i944, I and "Six quit Dewey Anti-Bias Board, Attack Governor for killing bill," New York Post, 26 March i 944, NAACP Papers, I 8, B, I I, 033; "Discrimination and Governor Dewey," New York Post, 3 I March i 944, 0530.

${ }^{21}$ Richard Norton Smith, Thomas E. Dewey and His Times (New York: Simon and Schuster, I982), 446 .

${ }^{22} N Y T$, i 8 February 1945, iv, Io.

${ }^{23}$ Ibid., 17 February 1945, 26.

${ }^{24}$ Smith, Dewey and His Times, 663. Journalist Warren Moscow recounted this conversation to Smith.

${ }^{25} N Y T$, I 2 May i 945, I 4. 
signed the New York State Fair Education Practices Act, outlawing racial and religious discrimination in higher education. ${ }^{26}$ By 1950 a similar law prohibited discrimination in public housing.

Dewey was acclaimed by civil rights groups for the SADC and some observers noted that it would be very useful for winning African Americans' votes if, as seemed likely, he was re-nominated by the Republicans in 1948 . The passage of the bill clearly demonstrated Dewey's skill as a chief executive and also firmly established him as the leading progressive force within the GOP. Ives-Quinn demonstrated what could be done with a thoughtful approach to the problem of discrimination. Here was a law, passed by a Republican governor that commanded bipartisan support and did not shock the GOP at large or imitate the Democrats. The question that remained was whether Dewey could translate his record into votes on the national level.

\section{"EVERY MAJOR POLITICAL ORGANIZATION HAS SEEN THE LIGHT BUT US": THE GOP AND AFRICAN AMERICAN REPUBLICANS}

Dewey had good reason to court the African American vote. The election of I 948 would mark a turning point in the history of civil rights; never before had it been such an important and, eventually, decisive issue in a presidential election. In 1944 it could be claimed, with the aid of some creative mathematics, that the African American vote decided the outcome. ${ }^{27}$ In 1948 there can be little doubt that it $\operatorname{did}^{28}$ As the 1944 Republican convention approached, the African American press had been largely hostile to Dewey. The "Weekly Survey of the Negro Press" reported "close to complete unanimity in the opposition" to a Dewey presidency. There was a perception that Dewey had made no "clear cut decisions" on race issues and widespread

26 Ibid., 6 April I948, I 3 and is September 1948, 33. The bill, like the SADC, was sponsored by Democrat Elmer F. Quinn. Irving Ives was now in the Senate, so Republican support came from Lewis Olliffe. The bill, which exempted religious institutions, became law in September.

${ }^{27}$ See Republican National Committee press release, "Statement by Herbert Brownell, Jr., Chairman, Republican National Committee," i i November i 944 . TED, S2, B38, Fi 5 . See also "Dewey needed shift of only 303,414 votes," New York. Herald Tribune, I 2 November i 944, NAACP Papers, i 8, B, i , 0622.

28 For the potential importance of the African American vote see, for example, Walter White, "Will the Negro Elect Our Next President," Collier's, 22 November, 1947, cited in Henry Lee Moon, Balance of Power: How the Negro Voted (Westport, CT: Greenwood Press Publishers, I 948) 21 4. See also, Topeka Plaindealer, 2 I November 1947, 2. By 1948 there were seventeen states, New York, Illinois, Pennsylvania, California, Ohio, Indiana, Michigan, New Jersey, Missouri, West Virginia, Maryland, Connecticut, Delaware, Kansas, Kentucky, Oklahoma and Massachusetts, where the African American could prove crucial. 
disappointment about the failure of anti-discrimination legislation in New York State. ${ }^{29}$ The Afro-American was highly critical of Dewey for siding with the South over the soldier voting bill of I 943 and the failure of New York's first anti-discrimination bill and claimed that even African Americans within the Republican Party were hostile to Dewey. ${ }^{30}$ After defeat in i 944, Dewey's campaign manager and confidante Herbert Brownell made numerous statements asserting that the African American vote could be decisive in the next presidential election and urged the GOP to take the necessary steps to win it. ${ }^{31}$ Dewey did not heed this advice, and, arguably, lost in 1948 as a result.

The morale of African American Republicans was haemorrhaging throughout the i940s. Robert Church, an African American businessman and lifelong Republican from Memphis, took the lead in demanding publicly that the GOP pay more attention to the requirements of African Americans and of the necessity of winning their votes, while Francis Rivers did so privately. Both men saw an excellent opportunity for the GOP to reconnect to African American voters if it was prepared to be bold. The GOP's approach to African Americans was, Church attested, backward looking and politically unsustainable. The Republican National Committee, unlike the Democratic Party, the Congress of International Organizations-Political Action Committee (CIO-PAC) and even the Communist Party, did not have a single African American in any policy-forming position. "Every major political organization has seen the light but us," complained Church. ${ }^{32}$

In August, I945 African American Republicans convened, under the chairmanship of Church, as the Republican American Committee and issued a "Declaration to the Republican Party." The declaration was fairly wideranging, but the bulk of it dealt with familiar themes such as anti-lynching, the poll tax and a Fair Employment Practices Commission (FEPC). The party's "entire attitude and strategy" towards African Americans, it declared, had to change if it was to win a presidential election. The committee was

29 "Weekly Survey of the Negro Press," 3 April to 9 April i 944, i. TED, S4, B 27, F6.

30 Plaindealer, 3 March i944, I. Baltimore Afro-American, 8 April i944. "Weekly Survey of the Negro Press," 3 April to 9 April 1944, г. TED, S4, B 1 27, F6. Similar sentiments were expressed in the Pittsburgh Courier, 8 April 1944, the Washington Tribune, undated and the New York People's Voice, 8 April i 944. "Weekly Survey of the Negro Press," 3 April to 9 April i944, I. TED, S4, B 1 27, F6.

31 Brownell was chairman of the Republican National Committee from I 944 to 1946 and Dewey's campaign manager in 1948. For his pronouncements on the importance of the African American vote see, for example, “Chairman's Report," Indianapolis, 22 January I 945 and RNC News Release, "Report of Herbert Brownell, Jr., Chairman to the Republican National Committee," I April i946, TED, S2, B38, Fi 5.

${ }^{32}$ Church to Brownell, i9 March 1945. TED, S4, B32, F29. Church had attended every Republican national convention from i9 2 to i 940. 
alarmed at the exodus of African Americans from the party and its lack of commitment to equal rights. The absence of an African American organisation until a few weeks prior to elections and the exclusion of African Americans from policy formulation were also attacked. ${ }^{33}$

This was militant stuff from the Republican American Committee, but it was telling Brownell, now the party chairman, nothing he did not already know. In addition to his analysis immediately after Dewey's defeat in I 944, in late 1945 Brownell urged Republicans to take a more considered approach to the winning of votes, including appeals to special interest groups. Again, he stressed the importance of African American voters and "the need for a careful and accurate presentation of the Republican point of view" to them. ${ }^{34}$ The creation, in November 1945, of the National Council of Negro Republicans was a step in the right direction. ${ }^{35}$

\section{“THE FRONT MEN FOR A MOTLEY COLLECTION OF MEDIOCRE PERFORMERS:” ELECTION STRATEGY IN 1948}

After sixteen years of opposition, the Republicans had renewed reason to be confident as the 1948 election approached. In April 1945 the politically indestructible Roosevelt had died, to be replaced by Harry Truman, the journeyman Senator from Missouri. Then, in 1946, the GOP gained control of both Houses of Congress for the first time since i 928 . It seemed highly unlikely that Truman would be re-elected. When Roosevelt died, many commentators wondered if the African American vote would remain loyal to the Democrats or become truly independent. ${ }^{36}$ Although the

33 The Republican American Committee, "Declaration to the Republican Party," 24-25 August i 945, NAACP Papers, I8, C, 29, OI70-0I72.

${ }^{34}$ Herbert Brownell, "Chairman's Report, Republican National Committee Meeting, Chicago, 7 December i945," TED, S2, B38, Fis. This report also dealt with appeals to female voters, veterans and young Republicans.

35 Republican National Committee News Release, "Report of Herbert Brownell, Jr., Chairman to the Republican National Committee," I April i 946, TED, S2, B 38 , Fi 5 . The states Brownell mentioned were Pennsylvania, Illinois, New York, Kentucky, Maryland, Ohio, California, Michigan, New Jersey, Missouri, Tennessee, Indiana and Virginia. See also an undated memorandum from Brownell, written as party chairman, TED, S2, B $38, F_{1}$. Another trusted Dewey lieutenant, Irving Ives, warned Dewey in early 1948 that the issues of anti-lynching, anti-poll tax, anti-discrimination and anti-segregation "are almost as difficult for the Republicans as for the Democrats." "Outline of subjects for inclusion in a discussion of national affairs: Part IV, Civil Rights." Ives to Dewey, 17 March I948. TED, Sio, B22, F5.

${ }^{36}$ Henry Lee Moon of the NAACP and the CIO-PAC believed that African American support had been for Roosevelt not his party. Moon, Balance of Power, 198. He expounded his theory in the New Republic, see Plaindealer, 22 October I948, I I. 
memory of Roosevelt was still fresh, there was a feeling that Truman could squander his predecessor's legacy. Nevertheless, Congressional Republicans remained reluctant to promote actively civil rights between 1944 and 1948 , even those measures promised in the GOP's I944 platform. ${ }^{37}$ Neither party, therefore, could confidently predict capturing the African American vote.

For the first eighteen months of the Truman presidency the low expectations of African Americans were justified. Mob violence against African Americans escalated throughout 1945 and 1946 and, after a number of particularly vicious lynchings, Truman finally met the National Emergency Committee to End Mob Violence on 19 September 1946. ${ }^{38}$ This group, led by Walter White, the Executive Secretary of the National Association for the Advancement of Colored People (NAACP), gave the president shocking details about attacks on African Americans and warned him that this was hurting America's image abroad. As a direct result of this meeting, Truman formed the President's Committee on Civil Rights (PCCR). ${ }^{39}$

There was a very deliberate shift in Truman's attitude towards African Americans and civil rights in late 1946. Henceforth Truman realised that he risked losing the African American vote, and the election, unless he delivered at least symbolic advances on civil rights. ${ }^{40}$ Nonetheless, under attack over strikes, rising prices as well as the sacking of Henry Wallace as Secretary of Commerce, Truman deemed it wise to wait until December 1946, with the

37 The GOP's I944 platform advocated a Congressional inquiry into segregation and discrimination in the armed forces, vowed to create a federal FEPC, pledged to pass a Constitutional Amendment outlawing the poll tax and promised "sincere efforts" to end lynching. For the complete plank on "Racial and Religious Intolerance," see Donald Bruce Johnson and Kirk H. Porter, National Party Platforms (Urbana: University of Illinois Press, 5 th edn, I973), 4I 2.

38 NAACP press release, "Truman promises committee. He will work to end mob violence," 20 September 1946, NAACP Papers, i 8, C, 26, 0430. The Committee represented fortyseven organisations. For more details on the lynchings in question see Robert Zangrando, The NAACP Crusade Against Lynching, 1909-1950 (Philadelphia: Temple University Press, I 980$),$ i $73-77$.

39 According to Walter White, on hearing of the situation in the South, Truman exclaimed: "My God! I had no idea it was as bad as that! We have to do something." Walter White, $A$ Man Called White: The Autobiography of Walter White (Athens and London: Brown Thrasher Books, University of Georgia, I 948), 330-3 I.

40 Truman was also sensitive to the Cold War context particularly after an NAACP delegation presented African American grievances to the United Nations in October 1947, greatly embarrassing the American government. 
mid-term elections safely out of the way, before issuing Executive Order 9808 to create the PCCR. ${ }^{41}$

In October 1947 "To Secure These Rights," the recommendations of the PCCR, was published and proved to be more wide-ranging and radical than Truman had anticipated. ${ }^{42}$ Truman commended the Commission's report as "an American charter of human freedom" but, although endorsing at least some of its findings, he refused to say how much of it he was prepared to implement. ${ }^{43}$ The recommendations of the PCCR required Congressional approval, meaning that this was not, therefore, a presidential crusade for civil rights. Truman still believed that, like Roosevelt, he could keep African Americans and white Southerners relatively happy. When it became apparent, however, that Southern opposition was going to be more militant than at first expected, he shelved plans for a civil rights bill. At this stage, Truman was disinclined to stand up to the South.

The Republicans' half-hearted and vacillating attitude towards civil rights was perhaps best illustrated by the failure to pass an FEPC bill. Many African Americans suspected that the GOP's support for an FEPC in 1944 was merely a ploy to win their votes in crucial northern states. ${ }^{44}$ By the time of the 1946 mid-term elections an FEPC law was no closer. African American fears were well-founded. In January 1947, as the Republicans assumed the leadership of both Houses of Congress, a startling admission from Joseph Martin, the Republican Speaker of the House of Representatives, delivered another serious blow to the morale and hopes of African American Republicans. Martin told a group of African American leaders that the party would not be pursuing an FEPC bill in the new session of Congress:

The FEPC plank in the 1944 Republican platform was a bid for the Negro vote, and they did not accept the bid. They went out and voted for Roosevelt. I'll be frank with you. We are not going to pass an FEPC bill ... We are supported by ... industrialists who would stop their contributions if we passed [the FEPC] ... I am not saying that I agree with them, but that is the situation we face, so we may as well be realistic ... we can't afford to pass the FEPC bill. ${ }^{45}$

${ }^{41}$ For correspondence between the NAACP and the PCCR see NAACP Papers, pt i 8, B, 25 , $0526-0727$. For editorial comment on the PCCR and the response of leading Republicans to it see frames $0826-852$.

${ }^{42}$ See "To Secure These Rights," Donald McCoy and Raymond G. O'Connor, Readings in Twentieth Century American History (London and New York: Macmillan, 1963), 53 I-4. For White's praise of the PCCR's findings see the Plaindealer, 21 November 1947, 2.

${ }^{43}$ Harvard Sitkoff, "Harry Truman and the Election of 1948: The Coming of Age of Civil Rights in American Politics," Journal of Southern History, 37 (I97I), 600.

44 Crisis, 53, March 1946, 72.

45 Pittsburgh Courier, 4 January 1947, 6, cited in William Berman, The Politics of Civil Rights in the Truman Administration (Columbus: Ohio State University Press, 1970), 59. 
Martin declared that the GOP's priority would be the passage of labour legislation. This astonishing confession encapsulated the Republicans' cynical attitude towards civil rights. It illustrated that the GOP was still very much the party of business; and where business interests and civil rights clashed the party would side with business. It was a frank admission that the FEPC plank in 1944 had been a political gambit and it was an equally frank admission that this had failed. As always, "bigger" issues took precedence, in this case the impending Taft-Hartley law. ${ }^{\mathbf{4 6}}$ Politics rather than sentiment would continue to dictate Republican policy. The best thing that could be said of Martin's statement was that at least it was honest. ${ }^{47}$

Dewey was duly re-nominated by the GOP in I948. The party then adopted a wide-ranging civil rights plank that endorsed the measures that the Eightieth Congress, in a large part due to the ambivalence of Republicans, had failed to pass. ${ }^{48}$ It included the perennial call for anti-lynching legislation, as well as demanding the abolition of the poll tax and the desegregation of the armed forces. However, plans to support the creation of a permanent FEPC were dropped to appease conservatives. ${ }^{49}$ There were also rumours that Dewey had been advised to tone down his support for civil rights if he wanted to be elected. ${ }^{\mathbf{5 0}}$ The Afro-American concluded that Dewey and his running mate Earl Warren, the liberal governor of California, were, despite their good records, "still only the front men for a motley collection of mediocre performers whose actions in Congress have been something less than lousy. "51 If the Republicans wanted African American votes, therefore, it was down to Dewey to win them.

Further pressure for action on civil rights from within the party came in the aftermath of the convention. Francis Rivers, perhaps Dewey's closest and most loyal African American ally, viewed the situation with increasing

46 The Taft-Hartley law was part of the GOP's drive to curb union power in the aftermath of the strikes of 1946. The act was passed in 1947 over Truman's veto. For more detail see James Patterson, Mr Republican (Boston: Houghton, Mifflin, I 972), 352-69 and Russell Kirk and James McClellan, The Political Principals of Robert A. Taft (New York: Fleet Press, I 967), I I9-32.

47 Berman, Politics of Civil Rights, 59. Berman does not intimate who attended this meeting or whether its content was meant for public consumption. It seems unlikely, however, that Martin, potentially writing off the African American vote, would have wanted this to be common knowledge.

${ }^{48}$ For the full text of the plank, see Johnson and Porter, National Party Platforms, 450.

49 Beyer, Thomas E. Dewey, I89. According to Beyer, the platform was adopted in twenty seconds.

50 Plaindealer, 9 July 1948 , I and 8.

${ }^{51}$ Afro-American, 3 July 1948. Cited in Donald McCoy and Richard Ruetten, Quest and Response: Minority Rights in the Truman Administration (Lawrence, University Press of Kansas, 1973), I 23. 
alarm during the summer of 1948 and urged Dewey to act quickly and positively. ${ }^{52}$ Rivers articulated three reasons why the Republicans should push civil rights legislation: principle, legislative efficiency, and expediency. Yet again Dewey was warned about the centrality of the African American vote, and yet again he ignored this advice. Rivers was extremely concerned that if the Republicans did not act then Truman would appear to be "the champion of idealism." $" 53$

Republican leaders could introduce civil rights bills in Congress, argued Rivers, with Dewey joining the fray once the inevitable Southern Democratic filibuster commenced; this in turn would draw Truman into the debate and associate him with Southern reactionaries. Regardless of the success or failure of civil rights legislation Dewey would benefit. Mirroring Democratic analysis, Rivers argued that civil rights legislation would be "passed due to DeweyRepublican leadership" or fail "because of lack of Truman leadership."

In August 1948 Church's Republican American Committee expressed its disappointment that the first Republican controlled Congress in sixteen years had not, despite platform pledges, taken any action on civil rights. The Committee restated its demands and urged the party to "nurture and cultivate the noticeable trend of colored voters back to our party" in $1946 .{ }^{55}$ To do this, the "entire attitude and strategy" towards African Americans had to change. Anti-lynching and anti-poll tax bills had to be "must" legislation; moreover, a special committee had to be established to examine the relationship between African Americans and the GOP. ${ }^{56}$ These demands were, predictably, ignored. Rivers's memorandum and the demands of the Republican American Committee demonstrated that African American

${ }_{52}$ Rivers to Charles Breitel, Counsel to the Governor, 20 July i 948. TED, S 5 , B280, F3o.

53 Ibid.

54 Ibid. A major concern of Democrats was that the Republican Party would be able to take credit for civil rights legislation or at least blame Democrats for its failure. For Democrat strategy see James Rowe, Jr., confidential report, “The Politics of 1948," i 8 September I 947. Papers of Kenneth Hechler, Dennis Merrill (general editor), Documentary History of the Truman Presidency, I4, 29-5 I. This memorandum has also been attributed to Clark Clifford.

${ }^{55}$ Earl Brown, "Negro Vote," Harper's Magazine, I 89 (July 1944), I 5 2. Cited in Albert Butler, "The Political Significance of Negro Migration from the South, I940-1962," Harry J. Vander III, The Political and Economic Progress of the American Negro, 1943-1963 (Dubuque, Iowa: William C. Brown Book Company, I 968), 9. Brown stated that a majority of African Americans in New Jersey, Ohio, Illinois, Indiana, Missouri, West Virginia, New York, and Kentucky had registered as Republicans. In a recent conference paper Timothy Thurber also suggested that a majority of African Americans had voted for the GOP in 1942. Thurber, "Seeds of the Southern Strategy: The Republican Party and African Americans, I 940-1952," (unpublished conference paper, BAAS, April 2001), 5.

56 Republican American Committee, press release, 27 August 1948, NAACP Papers, I 8, C, 29, $0216-0217$. 
Republicans were very far ahead of the party leadership. Rivers also illustrated that an imaginative response could be offered to Truman's recall of Congress in the summer of 1948 , if only the GOP were willing to exhibit some political acumen. ${ }^{57}$ Unfortunately for the GOP, much of Rivers's analysis proved prescient and Truman was indeed able to portray himself as "the champion of idealism."

The Republicans had been warned privately and publicly, internally and externally, from friend and foe alike that something positive had to be done to win back the African American vote. Truman's PCCR and demonstrated, if calculated, commitment to civil rights, together with the secession of Strom Thurmond's Dixiecrats, gave the Democratic Party a distinct edge in courting the African American vote. ${ }^{58}$ Nonetheless, Dewey remained better placed than any contemporary Republican to regain this vote or at least enough of it to deny Truman the presidency, but his failure to utilise his record and the advice of trusted allies was one of the greatest errors of the 1948 campaign.

\section{“THE CARICATURE OF THE TOTALLY POLITICAL MAN:” CIVIL RIGHTS IN THE CAMPAIGN OF 1948}

Dewey was an unenthusiastic campaigner who felt that the less he said the fewer people he would alienate. ${ }^{59}$ In October 1948 Commentary retained some hope that Dewey would speak out on civil rights, but noted that he had "never manifested any tendency to battle for lost or hazardous causes." Indeed, Dewey was the "caricature of the totally political man," geared towards elections and not governing, and exhibited no strong feelings on civil rights (although it conceded that "some of his best appointments" had been African Americans). ${ }^{60}$

Part of the difficulty for Dewey was that he was largely unknown to African Americans outside the Empire State. ${ }^{61}$ The Republican National

57 Truman had outmanoeuvred the GOP by recalling Congress in the summer of I948, ostensibly to see how genuine the Republicans were about their platform pronouncements. Throughout the campaign of 1948 , there was a perception that Congressional Republicans were only interested in civil rights legislation as a way to embarrass and split the Democrats. See, for example, K. M. Landis II, "Mockery in the Senate," Chicago Daily Sun Times, 4 August 1948, NAACP Papers, I8, C, 26, 0258.

58 The Dixiecrats had seceded at the Democratic convention over civil rights. Ironically, their desertion forced Truman to accept a much stronger civil rights plank than he had wanted, and he now had no choice other than to champion civil rights.

59 NYT, 3 October i 948, iv, 3.

60 James A. and Nancy F. Wechsler, "The Road Ahead for Civil Rights," Commentary, October 1948, p297-304. NAACP Papers, i 8, C, 26, 0303-0310.

61 McCoy and Ruetten, Quest and Responses, I 37. 
Committee sought to publicise Dewey's achievements through advertisements in the African American press, yet he barely referred to civil rights during his campaign. ${ }^{62}$ He mentioned the topic in Pennsylvania, and again in his home state on 2 I October. ${ }^{63}$ In the latter speech, made in tribute to the late $\mathrm{Al}$ Smith, Dewey demanded "justice and equal treatment for all" and asserted that he had "found it possible to find peaceful, honest solutions" to the problems of minorities, but this was the sum total of his pronouncements on civil rights. ${ }^{64}$

If Dewey's virtual silence on civil rights was not going to attract African American voters, it was likely that the pronouncements of Robert A. Taft were going to alienate them further. Taft, the GOP's conservative leader in the Senate, was sent South to campaign, either as a genuine effort to woo the South or, a more likely explanation, to remove him as a threat to Dewey on the national scene. Either way, his utterances owed more to the Republican party of 1928 than $1948 .^{65}$ He told an audience in South Carolina that the Republicans were "far more in accord with the views of the South than the policies of the Truman administration." Many Southern editors interpreted his words as an indication that Dewey would not be a strong proponent of civil rights. ${ }^{66}$ Some white Southern Republicans were inferring that, if elected, Dewey would rely on Taft on Southern matters. ${ }^{67}$ Taft was reported as saying: "substantially there is no difference between the Republican Party and Southern Democrats." 68 Taft may have been running a fool's errand in the South, but his remarks were potentially enormously harmful to the GOP's prospects of winning crucial northern African American votes. ${ }^{69}$

In the North both Republican and Democratic designs on the African American vote were threatened by the emergence of Henry Wallace and his Progressive Party. Wallace had been dumped as vice-president by Roosevelt in 1944 because he was too liberal on race issues and, therefore, unacceptable

${ }^{62}$ Ibid.

${ }^{63}$ Ibid., $137-38$.

${ }^{64}$ NYT, 22 October 1948, 4.

${ }^{65}$ The Republicans had run an essentially "lily-white" campaign in the South in 1928 and managed to make short-term gains there by, in effect, excluding African Americans from the party in the region. There is some debate as to whether this was done with Herbert Hoover's knowledge and blessing or not. See Richard B. Sherman, The Republican Party and Black America from McKinley to Hoover, 1896-1933 (Charlottesville: University Press of Virginia, 1973), ch. 9, Allen J. Lichtmann, Prejudice and The Old Politics: The Presidential Election of 1928 (Chapel Hill: University of North Carolina Press, 1979), I47-59 and Donald J. Lisio, Hoover, Blacks and Lilywbites (Chapel Hill and London: University of North Carolina Press, 1985), chs. 7-13.

${ }^{66}$ NYT, 22 October 1948, 7. Dewey avoided speaking in the South.

${ }_{67}$ Plaindealer, 29 October 1948, I. $\quad{ }_{68}$ Ibid., I 2 November 1948, 8.

${ }^{69}$ Jules Abels asserts that "Dewey and Brownell admit that they never entertained serious hopes of winning any state in the Solid South.” Abels, Out of the Jaws of Victory, 194. 
to the South, and then sacked as Secretary of Agriculture in I 946 by Truman. He was, according to the Research Division of the Democratic National Committee, at least initially a bigger threat to the Democratic hold on the African American vote than the Republicans were. Wallace openly endorsed civil rights, although his campaign was geared more towards foreign policy, and he spoke on the subject in the South as well as the North, and always to integrated audiences. Wallace attacked both parties on civil rights arguing that Truman did not believe in civil rights while the "Republicans remember the name of Abraham Lincoln but wilfully forget the principles of Abraham Lincoln." ${ }^{, 70}$

In June, however, Walter White expressed his concern that Wallace's presidential bid would lead to a more conservative Congress. ${ }^{71}$ White complained that he had tried to get Wallace to speak to the NAACP for years without success and contended that the former vice-president had largely ignored African Americans until ${ }_{\text {I } 944}{ }^{72}$ William Hastie, a senior NAACP figure and the governor of the Virgin Islands, believed that African Americans would not back Wallace. Speaking at Democratic party headquarters, he dismissed the Progressive party as "a puppet ... tied to the communist party," and described Wallace as "notoriously disinterested" in civil rights while Vice-President and in the cabinet. Hastie also warned of a "reactionary Republican" administration if Wallace did well. ${ }^{73}$ The prospect of Wallace taking votes away from Truman was not, therefore, in the interests of either the NAACP or the African American community. As late as September, the New York Times reported that many African Americans were still backing Wallace, ${ }^{74}$ but his campaign was heavily influenced by communists and by the time of the election his star had waned. ${ }^{\mathbf{7 5}}$

Dewey's faith in opinion polls was well known, and in I 948 he was ahead in just about every poll for virtually all of the campaign. The Crossley Poll of $\mathrm{s} 5$ October i 948, for example, put Dewey ahead in twenty-seven states, including many of those with significant numbers of African American voters. ${ }^{\mathbf{7 6}}$

70 NYT, 26 June i $948,4$.

72 Abels, Out of the Jaws of Victory, 208-09.

${ }^{73}$ NYT, I4 October 1948, 21.
75 Ibid., I 3 September 1948, I.
Plaindealer, 28 May 1948, 6. It was reported that Joseph H. Rainey a magistrate from Philadelphia was running for Congress on the Progressive party ticket. Rainey was the president of the NAACP's Philadelphia branch. For W. E. B. Du Bois's support of Wallace, see Plaindealer, 17 September 1948, 7. The Crisis concluded that ultimately few African Americans voted for Wallace suggesting the increasingly influence of Communists in the latter stages of his campaign as the reason. Crisis, 55, December 1948, 36 I.

${ }^{76}$ Press Release by Archibald M. Crossley of the Crossley Poll, is October I 948. TED, S2, B4, 6. For other polls predicting a Dewey victory see Harold Foote Gosnell, Truman's 
There appeared, therefore, little need for Dewey to embroil himself in civil rights or, indeed, any controversy. Yet in the latter stages of the campaign it was apparent that Truman was catching up. ${ }^{77}$ Towards the end of September reports were beginning to reach the Dewey camp that victory was no longer assured, with Truman making gains in California and Illinois. ${ }^{78}$ Furthermore, pollster Elmo Roper concluded that Dewey was attracting no more support than he had in 1944; disenchanted Democrats were backing the Dixiecrats or the Progressives or simply had not decided how to vote. ${ }^{79}$ As far as African Americans were concerned, an Associated Negro Press (ANP) survey predicted that not only would the vast majority of African Americans be voting for Truman, but also that he would win the election. The ANP's survey suggested that seven out of ten African Americans would be voting for Truman. ${ }^{80}$

\section{“THE DOCTOR CAN EXPECT TO LOSE A FEW PATIENTS": WHY DID DEWEY LOSE?}

In 1948 the polls were wrong and Truman won an extremely close election. They were not as inaccurate as the legendary Literary Digest poll of 1936, but, as the Chicago Daily News quipped: "the pollsters may say that the error was not great but when a man breaks into a dance after he has been pronounced dead, the doctor can expect to lose a few patients." electoral votes would have given Dewey a majority in the Electoral College and the importance of the African American vote to Truman is starkly illustrated by his slender majorities in California, Illinois, Kentucky, Missouri, Ohio and West Virginia (a total of I I 2 electoral votes). J. Howard McGrath, the Democratic chairman, recognised that the African American vote was extremely important in carrying California, Ohio and Illinois. ${ }^{82}$ Republican analysis agreed that the African American vote was important in Chicago,

\footnotetext{
Crises: A Political Biography of Harry S. Truman (Westport, CT: Greenwood Press, I980), 407-09.

77 Smith, Dewey, 524.

78 Ibid.

79 Ibid.

${ }^{80}$ Plaindealer, 29 October 1948, I and 5.

81 Abels, Out of the Jaws of Victory, 275. In the aftermath of the election, the Republican Party's Research Division reported that Gallup overestimated the Republican vote by $4.4 \%$, Crossley by $4.4 \%$ and Elmo Roper by $7.1 \%$. Ironically, Gallup and Crossley allowed for a $4 \%$ margin of error, which was less than the margin of victory in twenty-one states totalling 290 electoral votes. "The 1948 Election: A Statistical Analysis, May 1949." Papers of the Republican Party, Part 2, Reports and Memoranda of the Research Division of the Headquarters of the RNC, I938-1980 (henceforth PRP), reel I, frame 0774 .

${ }^{82}$ David McCullough, Truman (New York and London: Simon and Schuster, I 992), 7 I 3.
} 
New York and Philadelphia and conceded that it was "a potent influence" in California and Ohio. ${ }^{83}$ Dewey did, however, carry Delaware, Indiana and Maryland with African American votes. The Republicans, pertinently, did not win the majority of the African American vote in any state. ${ }^{84}$ Dewey even managed to poll even fewer African American votes in New York than he had in 1944, although he at least won his home state. ${ }^{85}$ Quite simply, victories in Ohio, California and Illinois would have resulted in a Dewey presidency; without the African American vote Truman would not have won the election.

Different groups were keen to take credit for this seemingly unlikeliest of victories. The farm vote especially in Ohio, Iowa and Wisconsin was important, particularly as Dewey's vote had dropped by 58,,000 in ten Midwest states since $1944{ }^{86}$ Brownell maintained that the crucial factor in 1948 was the farm vote; the GOP's own analysis concurred. ${ }^{87}$ The farm vote, while important, was not, however, the decisive factor Brownell, Truman and many commentators believed. In Illinois, it was clearly the African American vote that delivered victory to Truman. Elsewhere in the Midwest, Truman could have lost Iowa, Minnesota, Missouri, Wisconsin and Wyoming (fiftyfive electoral votes) and still scraped home. ${ }^{88}$ This reinforces the view that the African American vote was the vital factor in Truman's victory.

Predictions of a Dewey landslide may have actually deterred many Republicans from voting. Contemporary political analyst Samuel Lubell concluded, however, that the opposite was true: "far from costing Dewey the election, the [Democratic] stay-at-homes may have saved him almost as crushing a defeat as Landon suffered in I936."89 Wallace's vote helped the Republicans in Maryland, Michigan, New Jersey, New York, Ohio and

83 “The I 948 Election." PRP, reel I, frame 0793 . This analysis did not suggest what percentage of African Americans voted for the Democrats. It did, however, question the basis for Walter White's contention that $69 \%$ of African Americans had voted Democrat.

${ }^{84}$ Berman, Politics of Civil Rights, I $30-3 \mathrm{I}$.

85 Truman won 108,000 votes in Harlem compared to 34,000 for Dewey and 29,000 for Wallace. Chicago Defender, i 3 November i948, NAACP Papers, i 8, C, I8, 0358.

86 Abels, Out of the Jaws of Victory, 290. These states were Ohio, Illinois, Indiana, Michigan, Montana, Nebraska, Kansas, Missouri, Iowa and Wisconsin.

87 “The 1948 Election." PRP, reel I, frame 0772 . Moos notes that 682,382 people voted for congressmen but not for president. Moos, The Republicans, 445 .

${ }^{88}$ In Iowa, Wisconsin, and Wyoming Truman's majorities were very slim. Arthur Schlesinger et al. History of American Presidential Elections (New York: Chelsea House Publishers, 1985), 23 II.

89 McCullough, Truman, 714. Polls carried out by the Democratic party itself invariably predicted a Truman victory. Gosnell, Truman's Crises, 407-09. Taft commented ruefully that "the result of the election was a tragedy, largely because it was entirely unnecessary." Patterson, Mr Republican, 425 . 
Pennsylvania and might have aided the GOP in Illinois had he run there. Indeed, Wallace and Thurmond added respectability to the Dewey's performance; without them, Truman could have won a further eighty-five electoral votes, giving him a landslide.

African Americans were determined that their role be recognised. ${ }^{90}$ The Chicago Defender reckoned that between 80 and 85 per cent of African Americans had backed Truman. ${ }^{91}$ One Harlem editor asserted that African Americans "felt if they didn't support Truman no other politician would ever defy the Southerners again." population had grown by 40 per cent during the war and 80 per cent of them voted for Truman. ${ }^{93}$ What should have been made abundantly clear to the Republican Party was that they had to start winning African American votes and the best start they could make in this endeavour would be to rule out any further alliance with Southern Democrats. Yet there remained a justified fear among African Americans that this alliance would continue to stymie civil rights legislation in the new Congress.

Truman's legion of biographers agrees that he was a sincere advocate of civil rights. Most concede, however, that he believed in legal not social equality. ${ }^{94}$ Yet Truman's sincerity did not prevent him from using civil rights expediently. He only fully espoused civil rights after the Republicans had gained control of Congress in 1946; he only began campaigning actively for the African American vote and making tangible concessions on civil rights after the Democratic convention of 1948. By this stage he had little choice if he wanted to be elected. Sincere or not, therefore, Truman was still prepared to use civil rights cynically, a fact side-stepped by some of the historiography.

Truman gave the credit for his victory to the labour and farm votes, but there may have been more to this assessment than is immediately obvious. Clearly, one of his new administration's priorities would be the repeal of Taft-Hartley and labour was going to be his main ally in this endeavour. Truman could risk being associated with labour and, indeed, farmers as they were both extremely powerful interest groups, but African Americans were different. By effectively ignoring their contribution to his victory, Truman

90 Pittsburgh Courier, I 3 November 1948, NAACP Papers, I 8, C, I 8, $0355-0356$.

91 Chicago Defender, i 3 November i948, NAACP Papers, i 8, C, I 8, 0358.

${ }^{92}$ Richard Kirkendall, "Election of I 948," in Arthur Schlesinger, et al., History of Presidential Elections, 8, 31 39-40.

93 Albert D. Butler estimates that one and a half million people, almost all African American, left the South between I940 and 1950. Butler, "Negro Migration from the South," in Vander, Progress of the American Negro, 3.

${ }^{94}$ See, for example, Donald McCoy, The Presidency of Harry S. Truman (Lawrence, KS: University Press of Kansas, I984), Io6 or McCullough, Truman, 247. 
could refuse to accede to any African American demands. He made it very clear to Walter White in the aftermath of the election that he would not be pushing civil rights and implied that the African American vote was not an important factor in his victory. Truman's reticence is understandable: African Americans were not nearly as useful allies as labour and farmers, particularly if the South was to be rehabilitated. The South was more loyal than expected, and would not be reintegrated back into the Democratic Party by fulfilling pledges on civil rights. This reinforces the impression that Truman used civil rights callously.

The fact that Republican research on the African American vote was carried out by Herbert Brownell, one of his closest political allies, demonstrates that Dewey was aware of just how important this vote would be in 1948. Dewey clearly had an enviable record on civil rights, but he failed to translate this into African American votes. He had a great opportunity to win back at least some of the African American vote in I948: African Americans, unshakeable in their support for Franklin Roosevelt, had been beginning to waver and their votes were potentially, and probably briefly, independent. Moreover, it would not have taken many African American votes to give victory to Dewey. The most plausible explanation for Dewey's failure to court the African American vote seems to be overconfidence. He felt that he had hampered his cause in 1944 by being too abrasive, and in 1948 , ahead in every poll until late in the campaign, he decided to act like a President-inwaiting rather than a candidate.

Dewey assiduously avoided controversy and, in 1948, civil rights was controversial. Brownell, it spite of all the evidence, later declared that "Dewey's success in attracting the support of black and ethnic voters was one of our sources of inspiration." 95 Brownell clearly recognised the importance of the African American vote and the need for the GOP to broaden its support but his advice was ignored. Dewey did win in Harlem in 1942, but he lost there in I944, I 946 and I 948. This constitutes an emphatic, if perhaps unfair, reflection of the attitude of African American voters towards Dewey. Brownell was a sincere advocate of civil rights, but here his analysis has clearly been coloured by hindsight. If Dewey agreed with Brownell on the need to court minority voters then he certainly did not act on it. "Dewey had a complex about the Negro vote," concludes Abels, "which he had always courted in New York but never got." ${ }^{\mathbf{9 6}}$ Nevertheless, the rise to prominence of Brownell and Earl Warren were the most positive aspects of the Republican defeat; as Attorney General and Chief Justice respectively, they

95 Brownell and Burke, Advising Ike, 96.

${ }^{96}$ Abels, Out of the Jaws of Victory, 220. 


\section{98 Simon Topping}

were the source of the few constructive achievements in civil rights of the Eisenhower years.

In Dewey the Republicans had picked the best possible candidate from an African American point of view; he had a good record on appointments, had passed the SADC in New York and was generally fair to African Americans. Yet African Americans, like whites, "did not warm to him, did not trust him," and "they did not know where he stood on their special interests and on general black problems." 97 Americans were uncertain about where he stood on racial matters : 20 per cent believed he would support federal civil rights legislation, 24 per cent felt that he would leave it to the states to decide and $a$ further 20 per cent thought he opposed both state and federal action. ${ }^{\mathbf{9}}$ This reflected the perception that Dewey had "no apparent interest in general ideas" and "no sign of an underlying philosophy." Amsterdam Star-News editor C. B. Powell attributed Dewey's defeat in I 948 to the failure of the Republicans to win the African American vote, caused by the perception that the GOP was ambivalent about African Americans. Powell praised Dewey's gubernatorial record but concluded: "the fact that you failed to campaign specifically to the Negro population made it difficult to impress upon the masses the good that you have done for them. "100 This perhaps best encapsulates Dewey's failure to win the African American vote in 1948 and, with that failure, the presidency.

The final word on the election must go to Groucho Marx, who concluded: "the only way a Republican is going to get into the White House is to marry Margaret Truman."101

\footnotetext{
97 Smith, Dewey and his Times, 524. $\quad{ }^{98}$ Ibid. $\quad 99$ Beyer, Thomas E. Dewey, 24I.

100 C. B. Powell to Dewey, 23 November i 948 . TED, S5, B50, Fi 5.

101 Abels, Out of the Jaws of Victory, 270.
} 